\title{
Change in Toxicity of Model Arsenic Contaminant in the Presence of Humates and Activated Zeolites
}

\author{
Devard Iosifovich Stom ${ }^{1}$, Alexander Sergeevich Konovalov ${ }^{2}$, Mikhail Viktorovich Butyrin ${ }^{3}$, Vedeney \\ Viktorovich Tyutyunin ${ }^{4}$, Mikhail Naumovich Saksonov ${ }^{5} \&$ Tatyana Alexandrovna Penzina $^{6}$ \\ ${ }^{1}$ FSBEE HPE “Irkutsk State University”, Irkutsk, Russia \\ ${ }^{2}$ FSIS Baykal Museum ISC SB RAS, Irkutsk region, Russia \\ ${ }^{3}$ FSBI "Centre of an agrochemical service "Irkutskiy", Irkutsk region, Dzerzhinsk, Russia \\ ${ }^{4}$ FSBEE HPE SR “Irkutsk State Technical University”, Irkutsk, Russia \\ ${ }^{5}$ FSBEE HPE "Irkutsk State University”, Irkutsk, Russia \\ ${ }^{6}$ FSIS Siberian Institute of Plant Physiology and Biochemistry ISC SB RAS, Irkutsk, Russia \\ Correspondence: Devard Iosifovich Stom, FSBEE HPE "Irkutsk State University", Irkutsk, Russia. E-mail: \\ stomd@mail.ru, fray87@live.ru
}

Received: September $212014 \quad$ Accepted: September 25, $2014 \quad$ Online Published: December 29, 2014

doi:10.5539/mas.v9n1p223 URL: http://dx.doi.org/10.5539/mas.v9n1p223

\begin{abstract}
Using the methods of chemical analysis and bioassays, we investigated the toxicity and detoxication of model solutions containing arsenic salts. The ability of zeolites to absorb arsenic from model solutions was examined. Commercially available humic substances ("Powhumus", "Humate-80"), as well as zeolites, activated with their application were shown to reduce toxic effect of pollutants. Zeolite activated by degassing, decationization, thermal and chemical treatment showed the highest sorbent efficiency.
\end{abstract}

Keywords: detoxication, arsenic, arsenic pollution, humic substances, zeolite, activation of zeolites, bioassay

\section{Introduction}

To date, the negative effects of arsenic derivatives on the environment are fairly well known (Berg et al., 2007). On the other hand, there is evidence that in many cases, after binding toxicants to humic substances (HS), their aggressive potential is significantly reduced (Stom et al., 1992; Lin et al., 2004; Buschmann et al., 2006; Perminova et al., 2006; Janoš et al., 2010).

One of the most perspective methods of solid and liquid media detoxification, in particular for the elimination of arsenic contamination, is the use of various sorbents (Saada et al., 2003; Jeon et al., 2009; Jing et al., 2012). Natural zeolites deserve special interest as absorbers of various pollutants. They are distinguished by sufficiently cheapness and availability (Mohan and Pittman, 2007; Yadanaparthi et al., 2009).

Zeolites are microporous framework aluminosilicates. Voids in the frame occupied by various cations and water molecules. The volume of pores in the zeolite is up to $50 \%$ of the frame volume. They are capable of selectively binding cations of heavy metals, arsenic and several other substances due to the cation exchange properties (Wu and Zhou, 2009; Camacho et al., 2011).

In this context, the aim was to study methods of activation of natural zeolites (in particular HS) and neutralization of arsenic contamination in model experiments by modified sorbents.

\section{Method}

Solutions $\mathrm{Na}_{3} \mathrm{AsO}_{4}$, reagent grade, were used as a model of arsenic contamination. Natural zeolite from deposit "Sokirnitskoe", Transcarpathian Zeolite Plant (LLC "Etnakom") was used as the adsorbent. Crystallochemical formula of used zeolite is:

$$
(\mathrm{K}, \mathrm{Na}, 1 / 2 \mathrm{Ca})_{2} \mathrm{O} * \mathrm{Al}_{2} \mathrm{O}_{3} * 10 \mathrm{SiO}_{2} * \mathrm{H}_{2} \mathrm{O}
$$

Sorption capacity of the zeolite was evaluated by iodine (Kan et al., 2013).

Sources of HS were commercial preparations of "Humate-80" and "Powhumus". The first is a mixed humate 
$\mathrm{K} / \mathrm{Na}$, manufactured by LLC “Agricultural Technologies", Irkutsk. It is obtained by mechanochemical treatment of lignine and the mixture of $\mathrm{K}_{2} \mathrm{CO}_{3} / \mathrm{Na}_{2} \mathrm{CO}_{3}$. "Powhumus" is potassium humate (Humintech Ltd., Germany), produced by the standard wet alkaline extraction of oxidized coal (leonardite) (Perminova et al., 2006).

Zeolite was activated according to (Kan et al., 2013). For this purpose, $100 \mathrm{~g}$ of zeolite was washed with hot water $\left(60-70^{\circ} \mathrm{C}\right)$ to remove the clay inclusions. The washed zeolite was calcined at $400-450^{\circ} \mathrm{C}$ and placed in a solution of nitric acid $\left(60 \mathrm{~g} / \mathrm{dm}^{3}\right)$ for 24 hours for decationization. After decationization the zeolite washed with distilled water and calcined. Zeolite thus prepared was saturated with the respective solution $\left(5 \mathrm{~g}\right.$ of $\left(\mathrm{NH}_{2}\right)_{2} \mathrm{CO}, 5$ $\mathrm{g}$ of $\mathrm{NH}_{4} \mathrm{NO}_{3}, 40 \mathrm{~cm}^{3}$ of distilled water, $2.5 \mathrm{~cm}^{3}$ of $\mathrm{MnSO}_{4}, 7,5 \mathrm{~cm}^{3} \mathrm{HS}$ "Powhumus"). Alternatively, zeolite pre-prepared and saturated with a solution "Powhumus" at $1 \mathrm{~g} / \mathrm{dm}^{3}$ was used (in some experiments, instead of "Powhumus" used "Humate- 80 " at the same concentrations). $100 \mathrm{~g}$ of zeolite was impregnated by $50 \mathrm{~cm}^{3}$ of HS.

As control we evaluated the effectiveness of binding of arsenic by calcined zeolite without HS or other reagents added.

To determine the degree of absorption of the arsenic from the solution, the sorbents samples were placed in a column with a diameter of $20 \mathrm{~mm}$ and a height of $450 \mathrm{~mm}$, through which the test solutions were passed through for 60 minutes. The amount of arsenic in the source and the outlet solution was measured colorimetrically with diethyldithiocarbamate of silver in chloroform (State Standard 26930-86).

The following test objects were used: seeds of Lepidium sativum L. variety "ordinary cress" (JSC "Irkutsk seeds"), microalgae (Scenedesmus quadricauda (Turp.) Breb.), ciliates (Paramecium caudatum Ehrenberg), dry baker's yeast Saccharomyces cerevisiae (cultivar "Saf-moment", Lesaffre, France).

Toxicity of model solutions was evaluated by their effect on seed germination and seedling root length, by the change in fluorescence of chlorophyll of algae cells, by survival of ciliates, by bioluminescent of bacteria and by changes in foaming in the yeast slurry.

L. sativum seeds were placed in Petri dishes with filter paper "Blue Ribbon" (JSC "Plant Himreaktiv set"), to which $5 \mathrm{~cm}^{3}$ of the test solution was added. The dishes were incubated overnight at $31^{\circ} \mathrm{C}$. After counting, the seed plates were incubated for another day and the length of seedlings' roots was measured (Stom, 1982; Guidelines ..., 2002).

Levels of chlorophyll fluorescence were measured on "Fluorat-02-3M fluorometer" in continuous measurement mode after three days of incubation under the luminescent light. For each sample, mean fluorescence value was calculated as a mean of two measurements (Methodology ..., 2007).

In experiments with ciliates mortality in the test sample of $50 \%$ or more individuals per day was used as a criterion of acute toxicity (Methodology ..., 2006).

The degree of exposure of the test sample was judged by yeast foaming rate. For this, $1.36 \mathrm{~g}$ dry baker's yeast was suspended in $20 \mathrm{~cm}^{3}$ of the toxicant solution and $0.4 \mathrm{~g}$ glucose was added. The resulting suspension was placed in a thermostat at $30^{\circ} \mathrm{C}$ in test tubes containing $3 \mathrm{~cm}^{3}$ of the suspension. After 15 minutes, the resulting foam volume was determined. As the control we used yeast suspension prepared in tap water, dechlorinated by aging (Vyatchina et al., 2009).

All experiments were performed in at least 5 independent blocks with three replicate measurements in each. Statistical analysis of the data obtained was done using MS Excel data analysis package. Significance of the difference was determined by Student's $t$ test.

\section{Results and Discussions}

The effects of different HS in the concentration range $0.1-10 \mathrm{~g} / \mathrm{dm}^{3}$, as well as solutions $\mathrm{Na}_{3} \mathrm{AsO}_{4}$ in the concentration range $0.1-10 \mathrm{mg} / \mathrm{dm}^{3}$ on the germination of cress seeds are presented in Figure 1: 


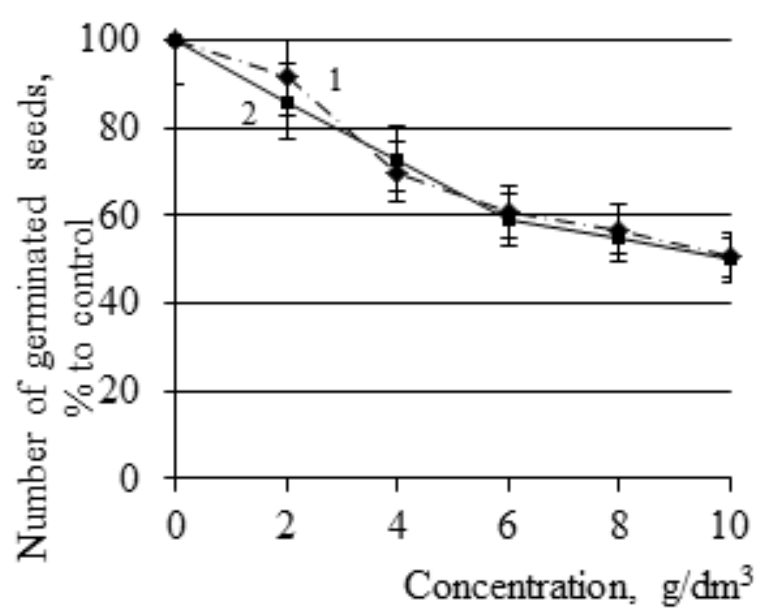

A

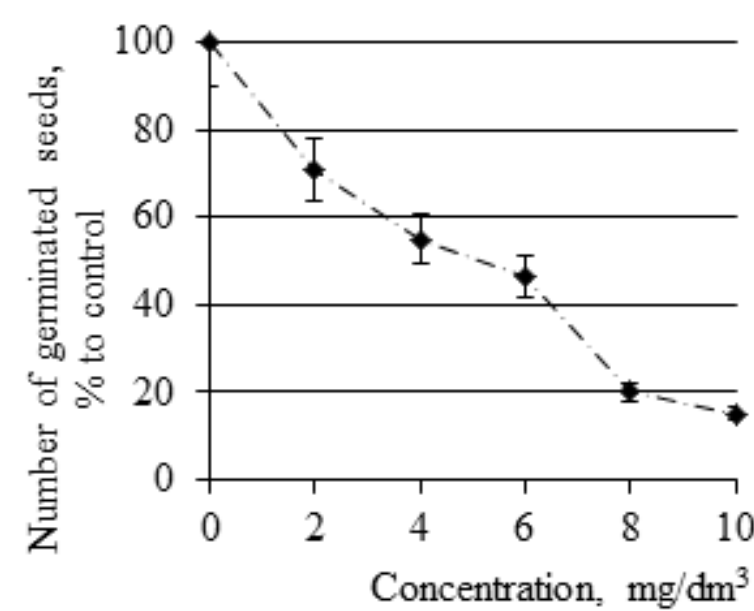

B

Figure 1. Influence of $\mathrm{HS}$ (A) and $\mathrm{Na} 3 \mathrm{AsO} 4$ (B) solutions of different concentrations on cress seeds germination ( $\%$ to control - dechlorinated water)

1. "Humate-80"

2. "Powhumus"

The investigated HS ("Powhumus" and "Humate-80") did not have a negative effect on seed germination at concentrations ranging from 0.1 to $2 \mathrm{~g} / \mathrm{dm}^{3}$. Although we observed a decrease in the number of germinated seeds of cress at concentration over $2 \mathrm{~g} / \mathrm{dm}^{3}$, even at the HS concentration of $9 \mathrm{~g} / \mathrm{dm}^{3} 50.2 \pm 4.8 \%$ of seeds germinated. Sodium arsenate in a concentration of $8 \mathrm{mg} / \mathrm{dm}^{3}$ inhibited seed germination by $80.1 \pm 7.9 \%$. $\mathrm{LC}_{50}$ of $\mathrm{Na}_{3} \mathrm{AsO}_{4}$ for cress seeds was $5.3 \mathrm{mg} / \mathrm{dm}^{3}$. Based on the obtained results, in the further analysis HS in concentration range of 0.1 to $1.0 \mathrm{~g} / \mathrm{dm}^{3}$ was used.

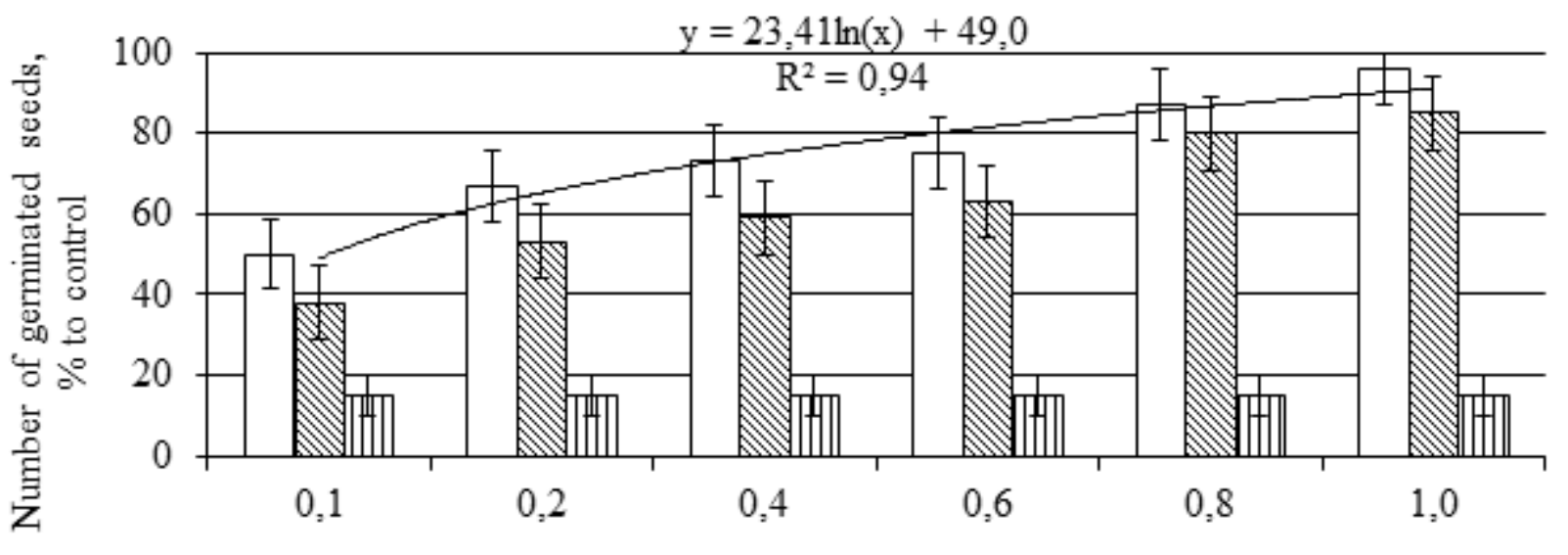

Concentration of $\mathrm{HS}, \mathrm{g} / \mathrm{dm}^{3}$

Figure 2. Combined effect of $\mathrm{HS}$ and $\mathrm{Na}_{3} \mathrm{AsO}_{4}$ solutions on seed germination in cress (\% to control-dechlorinated water):

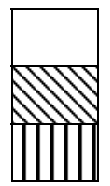

"Powhumus" $+\mathrm{Na}_{3} \mathrm{AsO}_{4} 10 \mathrm{mg} / \mathrm{dm}^{3}$

"Humate-80" + $\mathrm{Na}_{3} \mathrm{AsO}_{4} 10 \mathrm{mg} / \mathrm{dm}^{3}$

$\mathrm{Na}_{3} \mathrm{AsO}_{4} 10 \mathrm{mg} / \mathrm{dm}^{3}$ 
Figure 2 shows that HS at concentration $0.2 \mathrm{~g} / \mathrm{dm}^{3}$ reduced toxic effects of arsenic by $25,3 \pm 2,7 \%$. The toxicity of the model arsenic contaminant fell even to a greater extent at $1.0 \mathrm{~g} / \mathrm{dm}^{3}$ of "Powhumus". In this case, the number of germinated seeds was $96,1 \pm 8,7 \%$.

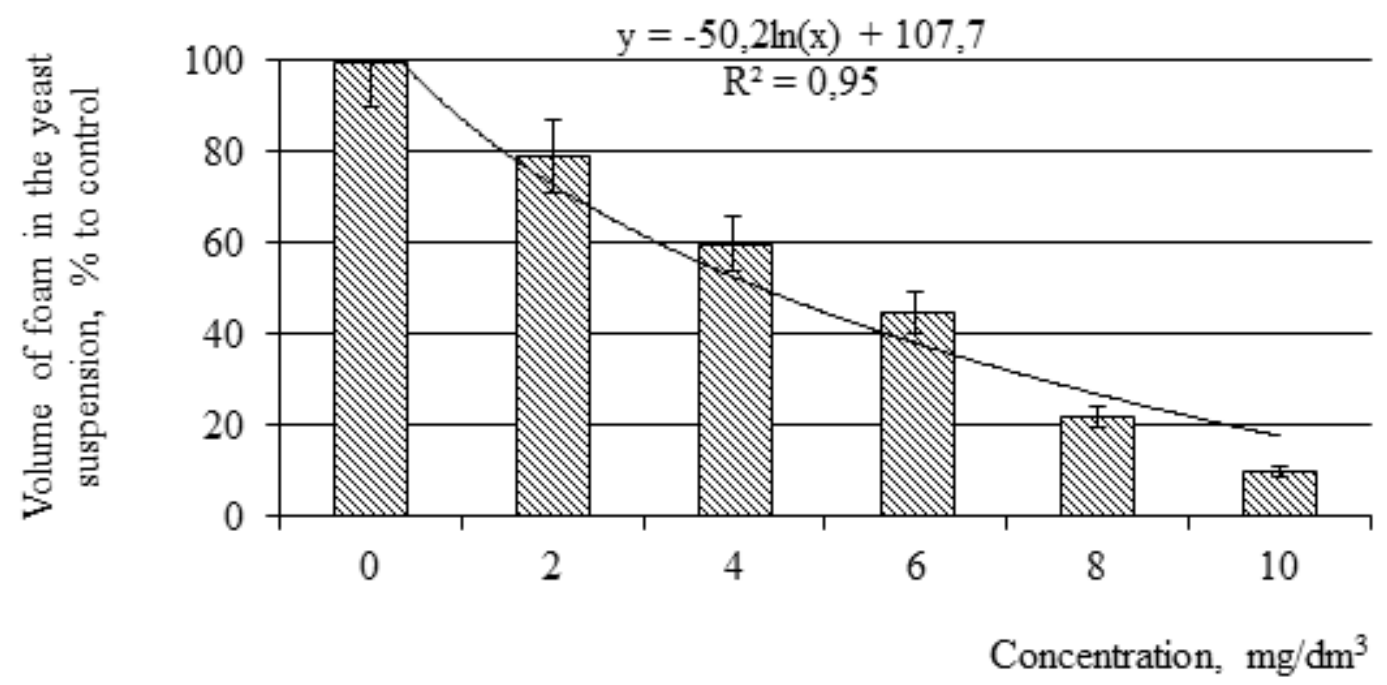

Figure 3. Influence of different concentrations of $\mathrm{Na}_{3} \mathrm{AsO}_{4}$ solutions on the volume of foam in the yeast suspension (\% to control - dechlorinated water)

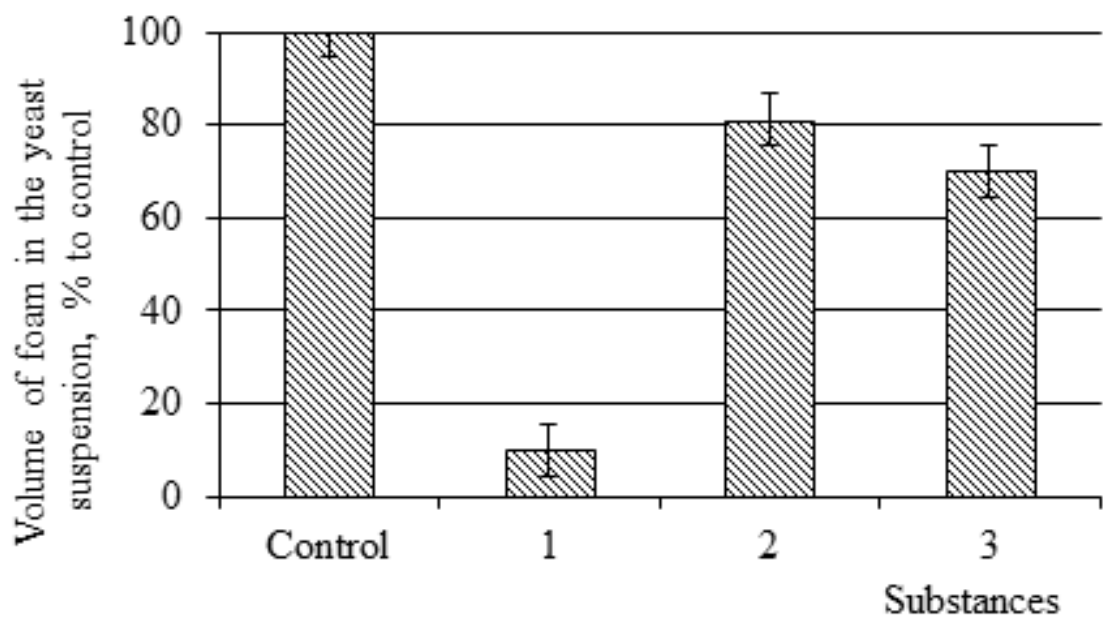

Figure 4. Combined effect of $0.2 \mathrm{~g} / \mathrm{dm}^{3} \mathrm{HS}$ and $10 \mathrm{mg} / \mathrm{dm}^{3} \mathrm{Na}_{3} \mathrm{AsO}_{4}$ on the volume of foam in the yeast suspension (\% to control - dechlorinated water)

$1-\mathrm{Na}_{3} \mathrm{AsO}_{4}$

2 - "Powhumus" $+\mathrm{Na}_{3} \mathrm{AsO}_{4}$

3 - "Humate- 80 " $+\mathrm{Na}_{3} \mathrm{AsO}_{4}$

Highly toxic concentration salt of arsenic for this bioassay was selected (Figure 3). "Powhumus" at a concentration of $0.2 \mathrm{~g} / \mathrm{dm}^{3}$ was found to be the most effective in reducing the toxic effects of arsenic on the foam formation in yeast suspension. It reduced the toxic effect of $\mathrm{Na}_{3} \mathrm{AsO}_{4}$ by $70.3 \pm 7.1 \%$ (Figure 4).

In chlorophyll fluorescence reduction bioassay using $S$. quadricauda cells the $\mathrm{LD}_{50}$ value was $1.5 \mathrm{mg} / \mathrm{dm}^{3}$ (Figure 5). 


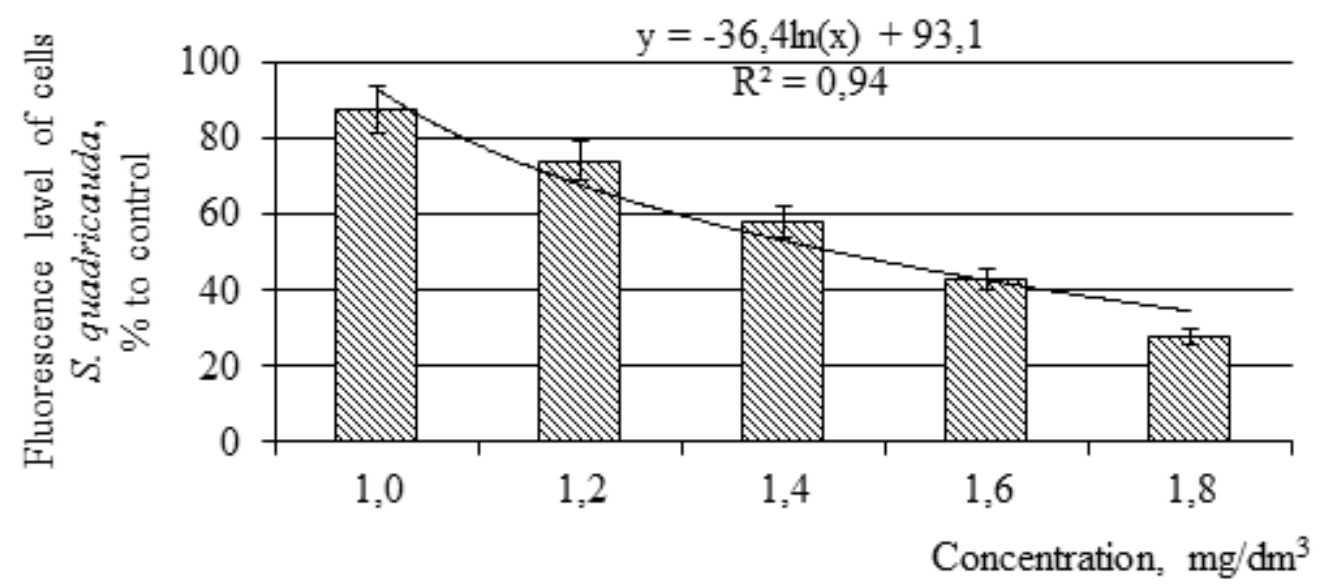

Figure 5. Influence of different concentrations of $\mathrm{Na}_{3} \mathrm{AsO}_{4}$ solutions on fluorescence of cell algae $S$. quadricauda (\% to control - dechlorinated water)

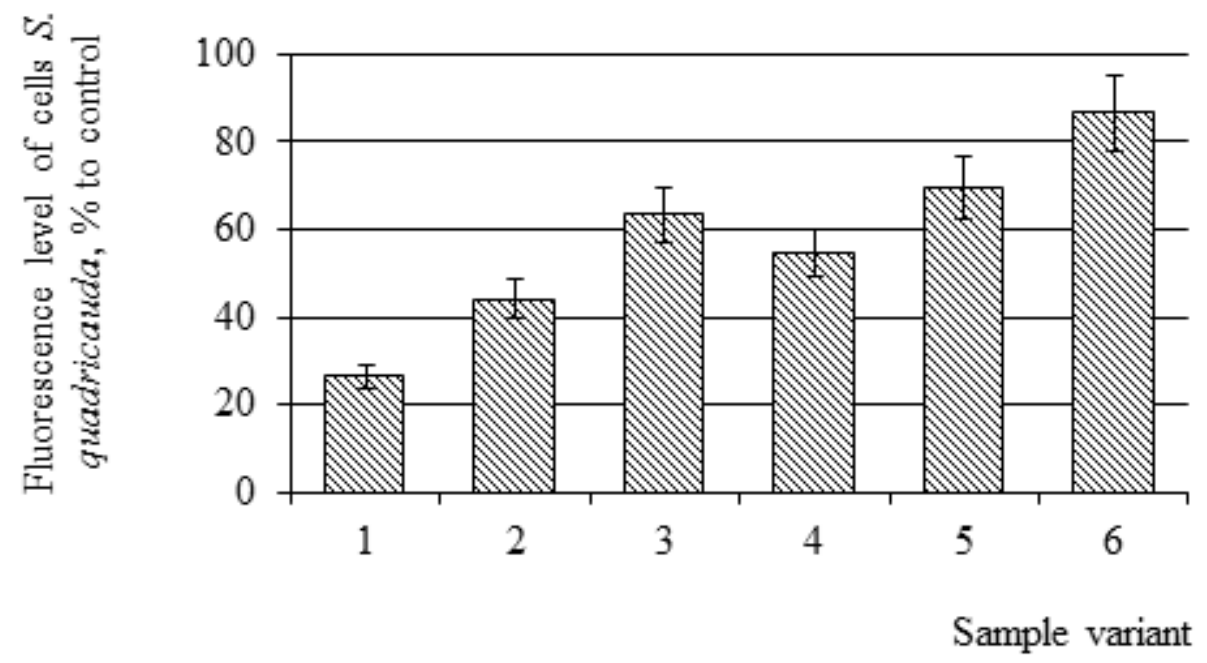

Figure 6. Combined effect of "Powhumus" and solutions $\mathrm{Na}_{3} \mathrm{AsO}_{4}$ on the fluorescence of algal cells $S$. quadricauda (in\% to control - dechlorinated water)

1. $1,8 \mathrm{mg} / \mathrm{dm}^{3} \mathrm{Na}_{3} \mathrm{AsO}_{4}$;

2. $1,8 \mathrm{mg} / \mathrm{dm}^{3} \mathrm{Na}_{3} \mathrm{AsO}_{4}+0,01 \mathrm{~g} / \mathrm{dm}^{3}$ "Powhumus";

3. $1,8 \mathrm{mg} / \mathrm{dm}^{3} \mathrm{Na}_{3} \mathrm{AsO}_{4}+0,05 \mathrm{~g} / \mathrm{dm}^{3}$ "Powhumus";

4. $1,5 \mathrm{mg} / \mathrm{dm}^{3} \mathrm{Na}_{3} \mathrm{AsO}_{4}$;

5. $1,5 \mathrm{mg} / \mathrm{dm}^{3} \mathrm{Na}_{3} \mathrm{AsO}_{4}+0,01 \mathrm{~g} / \mathrm{dm}^{3}$ "Powhumus";

6. $1,5 \mathrm{mg} / \mathrm{dm}^{3} \mathrm{Na}_{3} \mathrm{AsO}_{4}+0,05 \mathrm{~g} / \mathrm{dm}^{3}$ "Powhumus".

As seen in Figure 6, the intensity of chlorophyll fluorescence of microalgae cells treated with sodium arsenate at concentrations of 1.8 and $1.5 \mathrm{mg} / \mathrm{dm}^{3}$ was $26.4 \pm 3.2 \%$ and $54.5 \pm 6.1 \%$, while adding "Powhumus" at 0.05 $\mathrm{g} / \mathrm{dm}^{3}-63.1 \pm 6.4 \%$ and $86.4 \pm 8.8 \%$, correspondingly. 


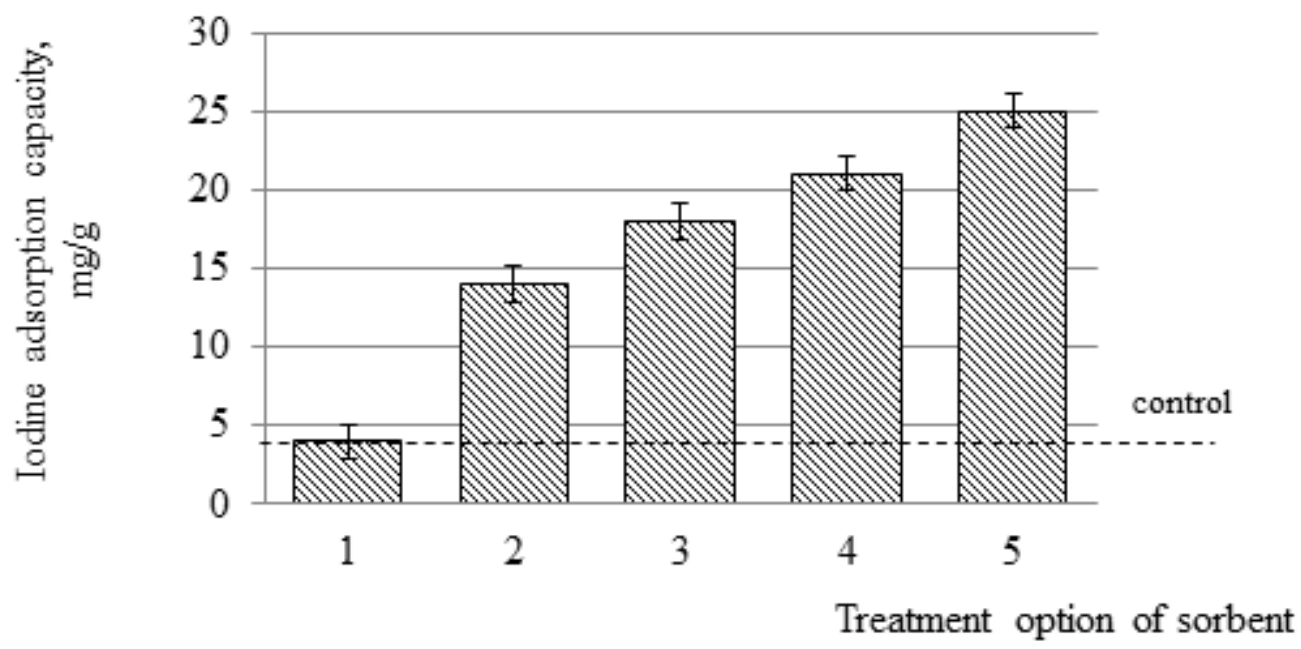

Figure 7. Sorption capacity of used zeolites depending on the method of processing:

1. Non calcined zeolite (control);

2. Calcined zeolite;

3. Zeolite calcined and saturated with HS "Humate-80";

4. Zeolite calcined and saturated with HS "Powhumus";

5. Zeolite modified by degassing, thermal and chemical treatment.

Figure 7 shows that the iodine sorption capacity of zeolite modified by degassing, thermal and chemical treatment was $25.0 \pm 1.1 \mathrm{mg} / \mathrm{g}$. Sorption capacity of modified zeolite saturated by $1 \mathrm{~g} / \mathrm{dm}^{3}$ "Powhumus" was $21.1 \pm 1.3 \mathrm{mg} / \mathrm{g}$, and in the application of the same concentration of "Humate- 80 " - $18.1 \pm 1.1 \mathrm{mg} / \mathrm{g}$.

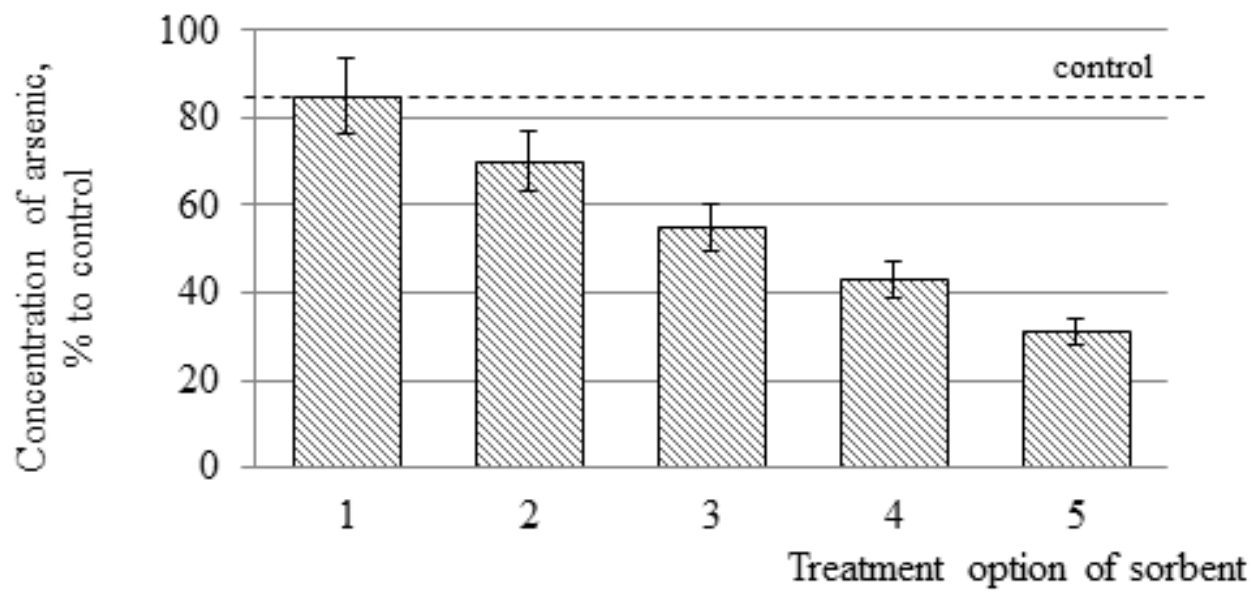

Figure 8. The effect of sorbent processing method on the uptake of $\mathrm{Na}_{3} \mathrm{AsO}_{4}$ at concentration of $100 \mathrm{mg} / \mathrm{dm}^{3}$ (1-5 as on Figure 7)

Figure 8 displays the results of the study of the ability of zeolites to bind arsenic from a model solution. Zeolite activated by degassing, thermal and chemical treatment absorbs arsenic from a model solution $41.2 \pm 3.9 \%$ more intensely than the control zeolite. Zeolite saturated by "Powhumus" and by "Humate-80" showed $27.2 \pm 3.1 \%$, and $15.7 \pm 2.2 \%$ higher binding ability than the control, correspondingly. 


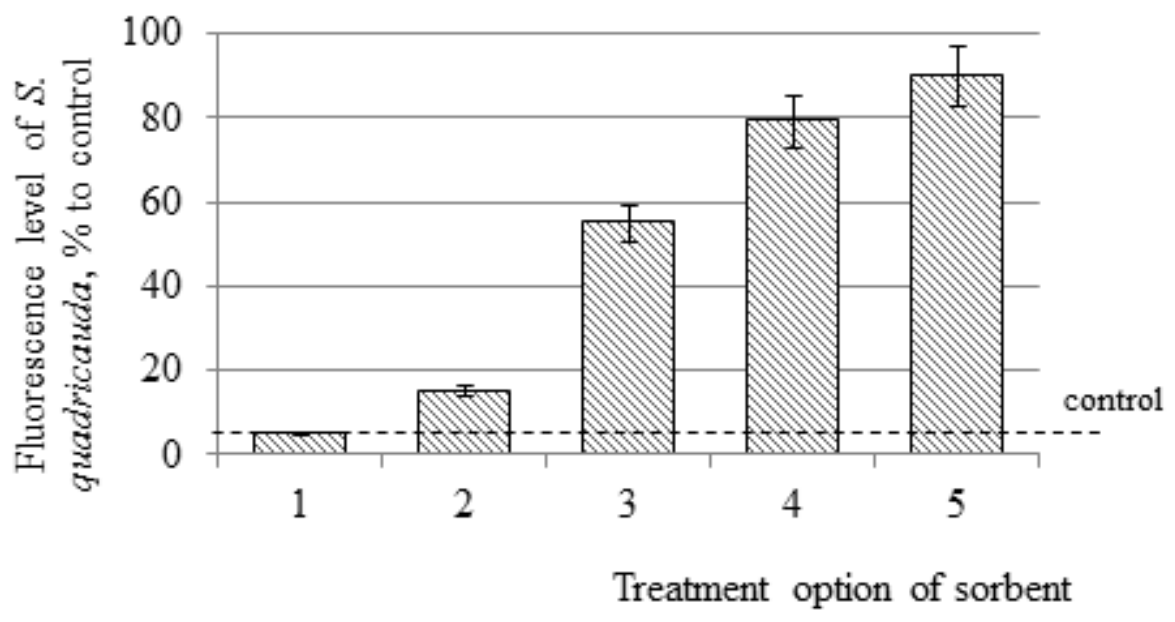

Figure 9. The effect of $100 \mathrm{mg} / \mathrm{dm}^{3} \mathrm{Na}_{3} \mathrm{AsO}_{4}$ solutions on fluorescence of $S$. quadricauda cells after passing through the modified zeolites (1-5 as on Figure 7)

As can be seen from figure 9 , the $100 \mathrm{mg} / \mathrm{dm}^{3} \mathrm{Na}_{3} \mathrm{AsO}_{4}$ solution passed through a column of calcined zeolite without adding HS or other reagents suppressed the level of chlorophyll fluorescence by more than $80 \%$. However, when zeolite, activated by degassing, thermal and chemical treatment (or saturated by "Powhumus") was used, the toxic effect of arsenic was on $60 \%$ lower relative to the calcined zeolite. The intensity of fluorescence of the cells of algae S. quadricauda reached $90.3 \pm 9.1 \%, 79.5 \pm 8.4 \%$ and $15.5 \pm 2.1 \%$ of the control, correspondingly. When bioassay solution passed through the zeolite saturated with HS "Humate- 80 ", the luminescence intensity of chlorophyll cells of microalgae was $55.7 \pm 5.9 \%$ relative to the control.

\section{Conclusions}

Zeolite activated with calcining at $400-450^{\circ} \mathrm{C}$, decationized and saturated with appropriate solution $(5 \mathrm{~g}$ of $\left(\mathrm{NH}_{2}\right)_{2} \mathrm{CO}, 5 \mathrm{~g}$ of $\mathrm{NH}_{4} \mathrm{NO}_{3}, 40 \mathrm{~cm}^{3}$ of distilled water, $2.5 \mathrm{~cm}^{3}$ of $\mathrm{MnSO}_{4}, 7,5 \mathrm{~cm}^{3}$ HS "Powhumus") the most effective in binding model arsenic contaminant $\left(\mathrm{Na}_{3} \mathrm{AsO}_{4}\right.$ salt aqueous solution at the concentration of 100 $\mathrm{mg} / \mathrm{dm}^{3}$ ). The same zeolite preparation had the highest iodine adsorption capacity (7).

Zeolite processed according to the method proposed by us (7) resulted in the lowest suppression of chlorophyll fluorescence of $S$. quadricauda cells by arsenic solution passed through a layer of absorbent.

\section{Acknowledgments}

This work was financially supported by the Ministry of Education of the Russian Federation within the framework of the project of the state task in the field of scientific activity (Task \# 13.1263.2014/K).

The authors are grateful to B.Stern, Humintech GmbH, LLC Agricultural technology for providing the HS samples and to N.I. Granina for the support work in this direction.

\section{References}

Berg, M., Stengel, C., Trang, P., Hungviet, P., Sampson, M., Leng, M., ... Fredericks, D. (2007). Magnitude of arsenic pollution in the Mekong and Red River Deltas - Cambodia and Vietnam. Science of The Total Environment, 372, 413-425. http://dx.doi.org/10.1016/j.scitotenv.2006.09.010

Buschmann, J., Kappeler, A., Indauer, U., Kistler, D., Berg, M., \& Sigg, L. (2006). Arsenite and Arsenate Binding to Dissolved Humic Acids: Influence of $\mathrm{pH}$, Type of Humic Acid, and Aluminum. Environ. Sci. Technol., 40, 6015-6020. http://dx.doi.org/10.1021/es061057+

Camacho, L. M., Parra, R. R., \& Deng, Sh. (2011). Arsenic removal from groundwater by $\mathrm{MnO}_{2}$-modified natural clinoptilolite zeolite: Effects of $\mathrm{pH}$ and initial feed concentration. Journal of Hazardous Materials, 189, 286-293. http://dx.doi.org/10.1016/j.jhazmat.2011.02.035

Guidelines for the determination of toxicity of water, bottom sediments, pollutants and drilling fluids by bioassay method (2002). M.: REFIA, NIA-Priroda. 
Janoš, P., Vávrová, J., Herzogová, L., \& Pilařová, V. (2010). Effects of inorganic and organic amendments on the mobility (leachability) of heavy metals in contaminated soil: A sequential extraction study. Geoderma, 159, 335-341. http://dx.doi.org/10.1016/j.geoderma.2010.08.009

Jeon, Ch., S., Baek, K., Park, J. K., Oh, Y. K., \& Lee, S. D. (2009). Adsorption characteristics of As(V) on iron-coated zeolite. Journal of Hazardous Materials, 163, 804-808. http://dx.doi.org/10.1016/j.jhazmat.2008.07.052

Jing, C., Cui, J., Huang, Y., \& Li, A. (2012). Fabrication, Characterization, and Application of a Composite Adsorbent for Simultaneous Removal of Arsenic and Fluoride. Applied Materials \& Interfaces, 4(2), 714-720. http://dx.doi.org/10.1021/am2013322

Kan, V. M., Konovalov, A. S., Taran, D. O., Bobrov, A. N., Butyrin, M. V., \& Stom, D. I. (2013). Detoxification method of wastewater contaminated with arsenic salts (Variants). Priority reference number 2013152455 from 26.11.2013.

Lin, H. T., Wang, M. C., \& Li, G. Ch. (2004). Complexation of arsenate with humic substance in water extract of compost. Chemosphere, 56, 1105-1112. Elsevier Science Ltd. http://dx.doi.org/10.1016/j.chemosphere.2004.05.018

Methodology for determining the toxicity of the waste, soil, sewage, surface and ground water by using blocking of ciliates (Paramecium caudatum Ehrenberg), FR. 1.39.2006.02506 FER 14.1:2:3.13-06 16.1:2.3:3.10-06 (2006). M.: MSU named after M.V. Lomonosov.

Methodology for determining the toxicity of water, aqueous extracts from soil, sewage sludge and waste, by changes in the level of chlorophyll fluorescence and the number of algal cells (2007). M.: Akvaros.

Mohan, D., \& Pittman, Ch. U. (2007). Arsenic removal from water/wastewater using adsorbents - A critical review. Journal of Hazardous Materials, 142(1-2), 1-53. http://dx.doi.org/10.1016/j.jhazmat.2007.01.006

Perminova, I. V., Kulikova, N. A., Zhilin, D. M., Grechischeva, N. Y., Kovalevskii, D. V., Lebedeva, G. F., ... Kholodov, V.A. (2006). Mediating effects of humic substances in the contaminated environments. Viable Methods of Soil and Water Pollution Monitoring, 1, 249-273. Protection and Remediation, Springer. http://dx.doi.org/10.1007/978-1-4020-4728-2_17

Raw materials and food. Colorimetric method for the determination of arsenic, State Standard 26930-86.

Saada, A., Breeze, D., Crouzet, C., Cornu, S., \& Baranger, P. (2003). Adsorption of arsenic (V) on kaolinite and on kaolinite-humic acid complexes. Role of humic acid nitrogen groups. Chemosphere, 51, 757-763. Elsevier Science Ltd. http://dx.doi.org/10.1016/S0045-6535(03)00219-4

Stom, D. I. (1982). Effect of Polyphenols on Shoot and Root Growth and on Seed Germination. Biologia Plantarum, 24(1), 1-6. http://dx.doi.org/10.1007/BF02898473

Stom, D. I., Geel, T. A., Schachova, G. V., Kuznetzov, A. M., \& Medvedeva, S. E. (1992). Bioluminescent method in studying the Complex Effect of the various Components. Archives of Environ. Contam. Toxicol, 22, 203-208. http://dx.doi.org/10.1007/BF00213286

Vyatchina, O. F., Zhdanova, G. O., \& Stom, D. I. (2009). Express acceptance of biological water quality analysis using Saccharomyces. Science. Journal of basic and applied research, 3(28), 86-88.

Wu, P., \& Zhou, Yu-sh. (2009). Simultaneous removal of coexistent heavy metals from simulated urban stormwater using four sorbents: A porous iron sorbent and its mixtures with zeolite and crystal gravel. Journal of Hazardous Materials, 168, 674-680. http://dx.doi.org/10.1016/j.jhazmat.2009.02.093

Yadanaparthi, S. K. R., Graybill, D., \& Wandruszka, R. V. (2009). Adsorbents for the removal of arsenic, cadmium, and lead from contaminated waters. Journal of Hazardous Materials, 171, 1-15. http://dx.doi.org/10.1016/j.jhazmat.2009.05.103

\section{Copyrights}

Copyright for this article is retained by the author(s), with first publication rights granted to the journal.

This is an open-access article distributed under the terms and conditions of the Creative Commons Attribution license (http://creativecommons.org/licenses/by/3.0/). 